\title{
Maternal Phylogenetics of Some Anatolian Cattle Breeds
}

\author{
Müge Doğan ${ }^{1, *}$, Mehmet Nizamlığlư ${ }^{2}$, Yusuf Özşensoy ${ }^{3}$, Ercan Kurar ${ }^{4}$, Zafer Bulut $^{2}$, Vahdettin Altunok ${ }^{2}$, \\ Ayşe Işık ${ }^{5}$, Aysun Çamlıdağ ${ }^{5}$ \\ ${ }^{1}$ Konya Veterinary Control Institute, Turkey \\ ${ }^{2}$ Department of Biochemistry, Faculty of Veterinary Medicine, Selcuk University, Turkey \\ ${ }^{3}$ Faculty of Veterinary Medicine, Cumhuriyet University, Turkey \\ ${ }^{4}$ Department of Medical Biology, Faculty of Medicine, Necmettin Erbakan University, Turkey \\ ${ }^{5}$ Cukurova Agricultural Research Institute, Turkey
}

Copyright $(2017$ by authors, all rights reserved. Authors agree that this article remains permanently open access under the terms of the Creative Commons Attribution License 4.0 International License

\begin{abstract}
In the current study, the mtDNA D-Loop region was analyzed in South Anatolian Red $(\mathrm{SAR}, \mathrm{n}=51)$, Anatolian Black (NB, $n=50)$, Anatolian Grey $(\mathrm{AG}, \mathrm{n}=54)$, Native Southern Anatolian Yellow (NSAY, n=51), East Anatolian Red (EAR, $n=54)$ and Zavot (ZAV, $n=19)$ cattle breeds $(n=279)$ to reveal diversity of mitochondrial DNA, differentiation of breeds, and relevance between genetic differentiations and geographic distributions. Blood samples were collected from native cattle breeds. Genomic DNA was isolated using a standard phenol/chloroform method. MtDNA D-loop region was amplified by PCR. After mtDNA sequence analysis, sequence of the D-Loop region was aligned with reference sequence. Haplotypes were determined and phylogenetic tree was constructed using BioEdit version 5.0.6, DNAsp version 5.10.01, MEGA 4.0 Network, Arlequin, Phylip and TreeView software. The sequence data was examined for nucleotide and haplotypes diversity, genetic distance between breeds visualized with Neighbor Joining tree and Median Joining Network, evaluated with mismatch distribution analyses, neutrality tests and AMOVA analyses. As a result in comparison with cattle breeds throughout the world, the higher nucleotide $(\pi=0.02240, \pm 0.0005)$ and haplotype diversity $(\mathrm{H}=0.9966, \pm 0.0006)$ higher haplotype number and also high genetic variation within and between the populations were determined in native Anatolian cattle breeds. These findings support the idea that Anatolia has been situated in a central position during the domestication process of the cattle species.
\end{abstract}

Keywords Native Cattle, mtDNA, D-loop, Sequencing, Phylogenetic, Domestication

\section{Introduction}

Archaeological and primary genetic studies indicated that cattle were probably the first domesticated animal in the area of Fertile Crescent which also involves Anatolia, 11,000 years ago [1]. Some genetic studies $[1,2,3,4,5,6,7,8,9,10]$ indicated that European cattle breeds spread from Anatolia to this region. More than 800 modern domestic cattle breeds are known worldwide.

Native breeds in an area that is a genetic inheritance will be transferred to the next generations in the area. However, FAO estimates that one breed of livestock becomes extinct every week [11]. The result of Hybridization studies on Anatolian native cattle breeds indicated that the genetic purity of the race began to disappeared. For this reason, Turkey's indigenous cattle breeds' genetic resources are in the process of extinction $[12,13]$. In order to protect native breeds, their genetic structures and genetic diversity must be determined. In phylogenetic studies, the most commonly used genetic marker is the sequence analysis of mitochondrial DNA (mtDNA) to determine the genetic difference and history of populations. MtDNA gives information about the maternal history, origin of the populations. It also became a key molecular marker for domestication studies, due to evolving rate is higher than nuclear DNA, its regions evolve even faster and does not undergo recombination. Displacement Loop (D-Loop) region is the most rapidly evolving region of mtDNA and gives information about domestication history of the livestock breeds. For that reasons, mtDNA D-Loop region sequence analysis has been a suitable diversity measure for phylogenetic studies [7].

In this study, Anatolian native cattle breeds (South Anatolian Red (SAR), Native Southern Anatolian Yellow (SAY), Anatolian Black (AB), Anatolian Grey (AG), East Anatolian Red (EAR) and Zavot) mtDNA D-Loop region polymorphisms were determined with DNA Sequence Analysis method. The purpose of this research is to reveal the domestication history of the Anatolian native cattle breeds and to explain the mtDNA diversity. It was carried out in order to compare European and Anatolian haplogroup diversity. 


\section{Materials and Methods}

\subsection{Sampling and DNA Isolation Procedures}

A total of 279 blood samples were collected from South Anatolian Red (SAR, $\mathrm{n}=51$ ), Native Southern Anatolian Yellow (SAY, $\mathrm{n}=51$ ), Anatolian Black (AB, $\mathrm{n}=50$ ), Anatolian Grey (AG, n = 54), East Anatolian Red (EAR, $n=$ 54) and Zavot (ZAV, $n=19)$ cattle. Genomic DNA samples were extracted by using a standard phenol/chloroform method [14]. Concentration, degradation and purity of DNAs were checked by Nanodrop 1000 and agarose gel (\% $0,6)$ electrophoresis.

\subsection{Amplification and Sequencing}

MtDNA D-loop region at position 15738 to 963 was amplified by forward primer (prot-RNA: CTGCAGTCTCACCATCAACC) [1] and revers primer (12SrNA-2: AGGATATAAAGCACCGCCAAG) [26]. Each multiplex for PCR was performed in $60 \mu$ reaction volume including $1 \times \mathrm{Mg}^{++}$free PCR buffer (Fermentas), $0.125 \mathrm{mM}$ dNTPs (Fermentas), $1.5 \mathrm{mM} \mathrm{MgCl}{ }^{++}, 0.375 \mathrm{U}$ of Tag polymerase (Fermentas), 2 - $17 \mathrm{pMol}$ each primer and $\sim 100 \mathrm{ng}$ of genomic DNA. Touchdown PCR profile was used with two steps. The first step was initial denaturation at $95^{\circ} \mathrm{C}$ for $4 \mathrm{~min}$, followed by 16 cycles of denaturation at $94^{\circ} \mathrm{C}$ for $30 \mathrm{sec}$, annealing beginning at $60^{\circ} \mathrm{C}$ and ending at $52^{\circ} \mathrm{C}$ for $30 \mathrm{sec}$ and extension at $72^{\circ} \mathrm{C}$ for $2 \mathrm{~min}$. Second step, 30 cycles of $94^{\circ} \mathrm{C}$ for $30 \mathrm{sec}, 52^{\circ} \mathrm{C}$ for $30 \mathrm{sec}$ and $72^{\circ} \mathrm{C}$ for 2 min were applied. The final extension of $72^{\circ} \mathrm{C}$ for $10 \mathrm{~min}$ was applied in all reactions. PCR products quality and purity were controlled with agarose gel $(\% 1,5)$ electrophoresis. The products cleaned with GENECLEAN ${ }^{\circledR}$ Turbo PCR Kit and sequencing reaction was applied according to Beckman Coulter DTCS kit's manufacturer's direction. The resulting, PCR products were loaded onto a Beckman Coulter CEQ-8000 Genetic Analysis System for capillary electrophoresis and sequencing were determined by sequence analysis using CEQ-8000 Lrf-b program with 25 second injection.

\subsection{Population History and Phylogenetic Analyses}

MtDNA sequences aligned and edited with BioEdit Version 7.0.9.1. [16] with references [2, 4, 17] sequences. After that, further analyses were performed using $621 \mathrm{bp}$ mtDNA D-Loop region.

The polymorphisms of aligned sequences, haplotype number, haplotype diversity $(h)$ and nucleotide diversity $(\pi)$ were estimated by using DnaSP Ver.5. software [18]. To identify Neighbor-Joining (NJ) tree was constructed by using K2P and pairwise deletion (1000 replicates) with MEGA Ver.4.0. software [19], PHYLIP Ver.3.69. [20] and TreeView [21]. AMOVA statistics were used to show the within population and between populations of the variation and analyses were performed with using Arlequin Ver.3.5.1.2. [22]. A Median Joining (MJ) network was generated to further investigate the possible relationships among the haplogroups by the program Network Ver.4.516. [23] to imagine the relationships among haplotypes of the population. To analyze the neutral theory, DnaSP Ver.5. [18] was used to calculate Tajima's $D$ [24] and Fu's Fs [25] values.

\section{Results and Discussion}

\subsection{Structure of the Populations}

MtDNA D-Loop region diversity and Fu's Fs and Tajima's D values of native cattle breeds in Turkey are shown in Table 1. A complete of 256 haplotypes were identified within 279 cattle samples and 37 of them were unique.

In the present study, it has been identified that Anatolian native cattle breeds have a large number of polymorphic sites on mtDNA D-loop region. In terms of nucleotide and haplotype diversity, they showed higher values than other known world cattle breeds $[2,4,5,6,7,8,10]$ when they were compared with all groups. Similarly, the Y chromosome specific markers in Turkish cattle breeds also showed high genetic diversity [26]. Genetic characterization which studied autosomal microsatellites and mtDNA reported that Turkish native cattle breeds had rich genetic diversity $[10,27]$. 
Table 1. Some statistical highlights about the studied breeds

\begin{tabular}{|c|c|c|c|c|c|c|}
\hline Breed & $\mathrm{N}$ & $\mathrm{Nh}$ & $(\pi)$ & $(h)$ & $\begin{array}{c}\text { Fu's } \\
\text { Fs }\end{array}$ & $\begin{array}{c}\text { Tajima's } \\
\mathrm{D}\end{array}$ \\
\hline $\mathrm{AG}$ & 54 & 44 & $0.01291( \pm 0.00132)$ & $0.983( \pm 0.011)$ & -36.702 & $-2.44867^{* *}$ \\
\hline $\mathrm{EAR}$ & 54 & 51 & $0.01809( \pm 0.00138)$ & $0.997( \pm 0.004)$ & -45.566 & $-2.49489^{* *}$ \\
\hline SAR & 51 & 48 & $0.02555( \pm 0.00303)$ & $0.997( \pm 0.005)$ & -33.427 & $-2.11975^{*}$ \\
\hline SAY & 50 & 48 & $0.01496( \pm 0.00121)$ & $0.998( \pm 0.004)$ & -51.578 & $-2.48566^{* *}$ \\
\hline AB & 51 & 47 & $0.01715( \pm 0.00184)$ & $0.996( \pm 0.005)$ & -34.337 & $-2.43821^{* *}$ \\
\hline ZAV & 19 & 18 & $0.01372( \pm 0.00257)$ & $0.994( \pm 0.019)$ & -9.711 & $-2.15258^{*}$ \\
\hline
\end{tabular}

$* \mathrm{P}<0.10, * * \mathrm{P}<0.05$

N: Number of samples, Nh: Number of haplotypes, h: Haplotype diversity, $\boldsymbol{\pi}$ : Nucleotide diversity, Fu's Fs: Fu's statical F value, Tajima's D: Tajima's statical D value SAR: South Anatolian Red, SAY: Native Southern Anatolian Yellow, AB: Anatolian Black, AG: Anatolian GreY, EAR: East Anatolian Red and ZAV: Zavot.

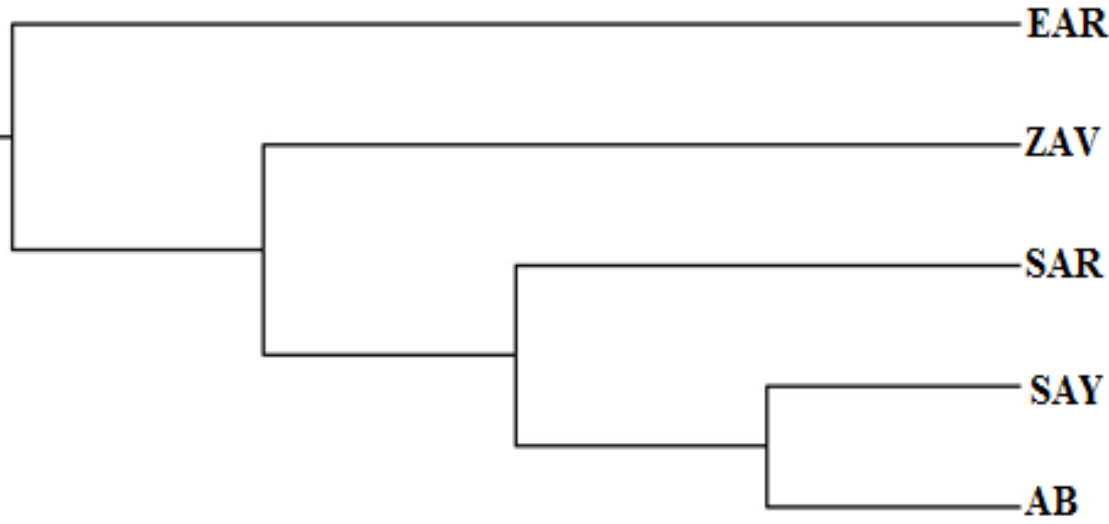

Figure 1. Neighbour Joining tree constructed on $\mathrm{F}_{\mathrm{ST}}$ distances of all the Anatolian native breeds.

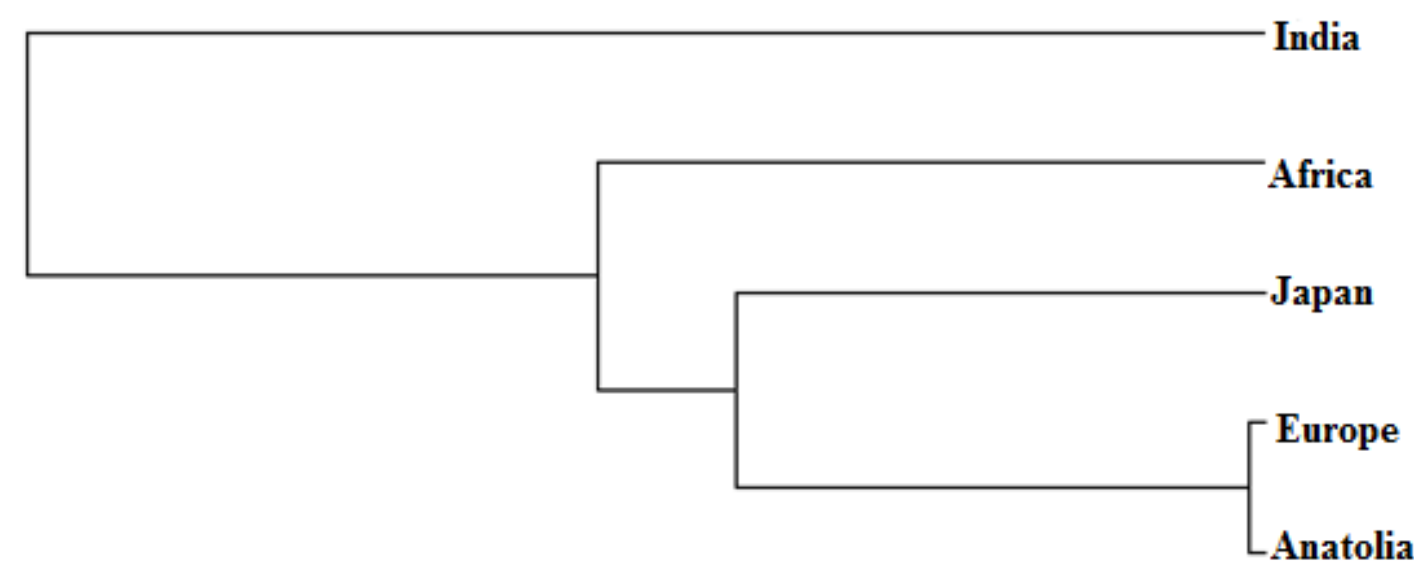

Figure 2. Neighbour Joining tree constructed on $\mathrm{F}_{\mathrm{ST}}$ distances of Anatolian cattle and references sequence. 


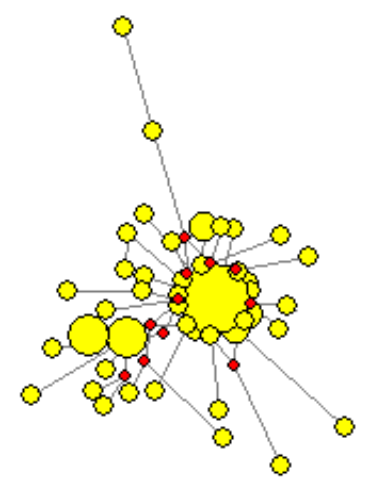

Anatolian native cattle breeds

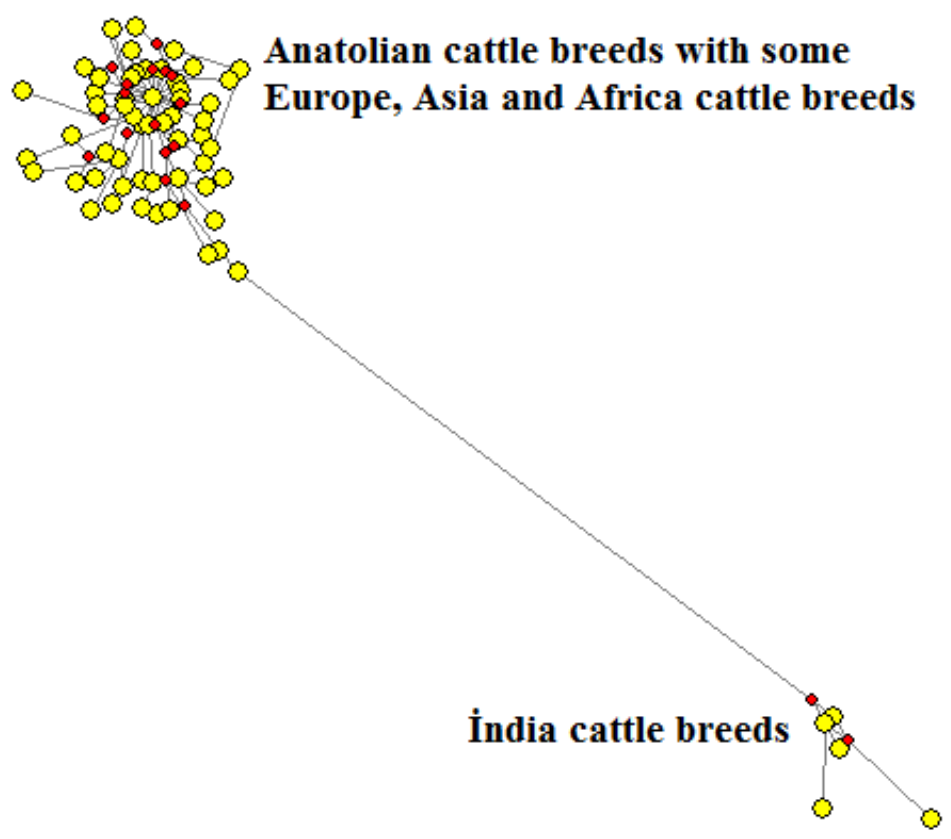

Figure 3. Median Joining Network analysis of Anatolian and Europe, Asia, Africa and İndia native cattle populations' haplotypes

Phylogenetic relations of the samples were examined by $\mathrm{NJ}$ tree constructions $[20,21,23] . \mathrm{F}_{\mathrm{ST}}$ values calculated by applying 1000 permutation and these were found very high and statistically significant $(\mathrm{p}<0.001)$. Anatolian native cattle breeds $\mathrm{F}_{\mathrm{ST}}$ distances showed that there was a low genetic differentiation between $\mathrm{AB}, \mathrm{SAY}$ and SAR cattle breeds (Figure 1) [22]. Some Europen, Asian, African and Indian native cattle breeds of mtDNA D-loop region sequences derived from the Genebank and NJ tree (cladogram) were drawn with Anatolian cattle breeds, according to genetic distance values $\left(\mathrm{F}_{\mathrm{ST}}\right)$. Under $\mathrm{F}_{\mathrm{ST}}$ distances, all Anatolian cattle breeds have been involved in the same branch with European breeds (Figure 2).

$\mathrm{F}_{\mathrm{ST}}$ results demonstrated that Anatolian native cattle breeds had very high degree of differentiation. Results were also compatible with intra-race haplotype and nucleotide diversity. It was determined that diversity was very high. According to the Neighbor Joining (NJ) tree, we found that two races (AB and SAY) are genetically closest. The population of $A G$ has been identified as the furthest from all other native cattle breeds location. Some STR analyses $[9,10]$ also have reported that AG breeds population is a separate branch on. In this study, genetic relationships of Anatolian native cattle breeds closer to European breeds and other side India breeds are seen as completely separate from others, like some genetic studies $[3,4,6]$.

A data file was created for AMOVA analysis by using $F_{\mathrm{ST}}$ analysis results. AMOVA analysis results showed that genetic differences level was very high $(1.87 ; \mathrm{p}<0.05)$ between the groups [22]. And also it was determined that variation within populations is higher than variation between populations and the same results have been reported in many studies $[9,10,28,29,30,31]$.

\subsection{History of the Populations}

Based on neutrality test findings (Table 1: Fu's Fs and Tajima's D values), all native cattle breeds seem to have an expansion of population [32]. Median Joining network obtained from haplotypic data is shown in Figure 3 [23].

Median Joining network showed that all Anatolian cattle haplotypes condensed around a centric area. This centric area shows us that old haplotypes exist here and Anatolian haplotype is genetically closer range with Europe, Asia and Africa haplotypes. Each sequence described almost a specific haplotype and it has a star-like model. When we take into account this analysis results, we can say that Anatolian native cattle breeds originated from first domesticated haplogroups [23]. All these results suggest that Turkey is a central localization for cattle domestication as Troy et al. 2001.

\section{Conclusions}

All analytical results have confirmed that Anatolia was a domestication center for cattle and these breeds have critical importance due to their close proximity to the domestication center. The NJ tree's results and structure analysis showed that the Anatolian native cattle breeds are consistent with their modern geographical locations. This study made it clear that the native cattle breeds contained high level of genetic variability and preserved mtDNA diversities.

\section{Acknowledgements}

The financial support of this study is from Selcuk 
University (PhD Thesis Project Number: BAP 09202015) and the study is a part of TURKHAYGEN I project (TÜBİTAK- KAMAG 106G005)

\section{REFERENCES}

[1] Zeder MA. (2008). Domestication and early agriculture in the Mediterranean Basin: Origins, diffusion, and impact. Proc Natl Acad Sci, 105 (33), 11597-11604.

[2] Loftus RT, Machugh DE, Bradley DG, Sharp PM, Cunningham P. (1994). Evidence for two independent domestications of cattle. USA. Proc. Natl Acad Sci, 91, 2557-2761.

[3] Loftus RT, Ertugrul O, Harba AH, El-Barody MA, Machugh DE, Park SD. (1999). Bradley DG. A microsatellite survey of cattle from a centre of origin. The Near East. Mol Ecol, 8, 2015-2022.

[4] Bradley DG, Machugh DE, Cunnıngham P, Loftus RT. (1996). Mitochondrial diversity and the origins of African and European cattle. Anthropology, 93, 5131-5135.

[5] Hiendleder S, Lewalski H, Wassmuth R, Janke A. (1998). The complete mitochondrial DNA sequence of the domestic sheep (ovaries) and comparison with the other major ovine haplotype. J Mol Evol, 47, 441-448.

[6] Troy CS, MacHugh DE, Balley JF, Magee, DA, Loftus TR, Cunningham P, Chamberlain AT, Sykes BC, Bradley DG. (2001). Genetic evidence for Near-Eastern origins of European cattle. Nature, 410, 1088-1091.

[7] Bruford MW, Bradley DG, Lu1kart G. (2003). DNA markers reveal the complexity of livestock domestication. Nat Rev Genet, 4, 900-910.

[8] Özdemir M. (2006).Türkiye yerli sığır ırklarında mitokondriyal DNA polimorfik yapılarının PCR-RFLP ve DNA dizi analizi yöntemleri ile incelenmesi. PhD Thesis.

[9] Özkan E. (2005). Türkiye'de Yetiștirilen Yerli ve Kültür Sığır Irklarının Genetik Yapılarının Mikrosatelitler ile İncelenmesi. $\mathrm{PhD}$ Thesis.

[10] Özşensoy Y. (2011).Türkiyede Bulunan Bazı Yerli Sığır Irklarının Genetik Karakterizasyonun Mikrosatellitlerle İncelenmesi. PhD Thesis.

[11] Scherf B.J. (ed.) (2000): World watch list for domestic animal diversity, Food and Agriculture Organization of the United Nations (FAO), Rome, (http://www.fao.org).

[12] Ertuğrul M, Akman N, Dellal G, Goncagül T. (2000). Hayvan gen kaynaklarının korunması ve Türkiye hayvan gen kaynakları. Ankara Türkiye Ziraat Mühendisliği V. Teknik Kongresi.

[13] Ertugrul M, Dellal G, Elmacı C, Akın AO, Pehlivan E, Soysal M, Arat S. (2010). Çiftlik hayvanları genetik kaynaklarının korunması ve sürdürülebilir kullanımı. Ankara. Türkiye Ziraat Mühendisligi VII. Teknik Kongresi Kitapçı̆̆ı, 179-198.

[14] Sambrook J, Fritsch EF, Maniatis T (1989). Molecular Cloning: A Laboratory Manual, Vol. I, 2nd edition. Cold
Spring Harbor Laboratory Press.

[15] Don RH, Cox PT, Wainwright BJ, Baker K, Mattick JS. (1991). Touchdown PCR to circumvent spurious priming during gene amplification. Nucleic Acids Res, 19, 4008.

[16] Hall T. (2001). BioEdit version 5.0.6 North Carolina State University. [Cited 2013 Mar 13]. Available from URL: http://www.mbio.ncsu.edu/bioedit/bioedit.html.

[17] Lai SJ, Liu PY, Liu XY, Li WX, Yao GY. (2006). Genetic diversity and origin of Chinese cattle revealed by mtDNA D-loop sequence variation. Mol Phylo Evol, 38, 146-154.

[18] Librado P and Rozas J. (2009). DnaSP v5: A software for comprehensive analysis of DNA polymorphism data. Bioinformatics, 25, 1451-1452.

[19] Kumar S, Dudley J, Nei M, Tamura K (2008): MEGA: A biologist-centric software for evolutionary analysis of DNA and protein sequences. Brief Bioinform, 9, 299-306.

[20] Felsenstein J. Phylip (2005). (Phylogeny Inference Package) Version 3.6. Department of Genome Sciences, University of Washington Seattle. [Cited 2013 Mar 11]. Available from URL: http://evolution.genetics.washington.edu/phylip.html.

[21] Page RDM. (2002). Visualizing phylogenetic trees using TreeView. Current Protocols in Bioinformatics. John Wiley and Sons pres.

[22] Excoffier L, Smouse PE, Quattro JM. (1992). Analysis of molecular variance inferred from metric distances among DNA haplotypes: application to human mitochondrial DNA restriction data. Genetics, 131(2), 479-491.

[23] Bandelt HJ, Forster P, Röhl A. (1999). Median-joining networks for inferring intraspecific phylogenies. Mol Biol Evol, 16, 37-48.

[24] Tajima F. (1989). Statistical method for testing the neutral mutation hypothesis by DNA polymorphism. Genetics, 123: 585-595.

[25] Fu YX. (1997). Statistical tests of neutrality of mutations against population growth, hitchhiking and background selection. Genetics, 147: 915-925.

[26] Özșensoy Y, Kurar E, Bulut Z, Nizamlığlu M. (2014). Y chromosome analysis of native Turkish cattle breeds by microsatellite markers. Turk J Biol, 38, 388-395.

[27] Kurar E, Özşensoy Y, Doğan M, Bulut Z, Altunok V, Işık A, Çamlıdağ A, Nizamlıŏlu M. (2011). Autosomal and mitochondrial genetic diversity of Turkish native cattle breeds. 8th Global Conference on the Conservation of Animal Genetic Resources. 4-8 October 2011, Tekirdag, Türkiye.

[28] Luikart GL, Gielly L, Excoffier JD, Vigne J, Bouvet P. (2001). From the Cover: Multiple maternal origins and weak phylogeographic structure in domestic goats. Proc. Natl Acad Sci, 98, 5927-5932.

[29] Wiener P, Burton D, William JL. (2004). Breed relationships and definition in British cattle: A genetic analysis. Heredity, 93, 597-602.

[30] Mateus JC, Penedo MCT, Alves VC, Ramos M, Rangel-Figueiredo T. (2004). Genetic diversity and differentiation in Portuguese cattle breeds using microsatellites. Int Soc Anim Genet, 35, 106-113. 
[31] Li MH, Zerabruk M, Vangen O, Olsaker I, Kantanen J. (2007). Reduced genetic structure of north Ethiopian cattle revealed by Y-chromosome analysis. Heredity, 98, 214-21.
[32] Depaulis F, Mousset S, Veuille M. (2003). Power of neutrality tests to detect bottlenecks and hitchhiking. J Mol Evol, 57, 190-200. 